\title{
ON-LINE LEARNING MODULES FOR WASTE TREATMENT, WASTE DISPOSAL AND WASTE RECYCLING
}

\section{Prof. MSc. Paul O’CAllaghan, PhD. ${ }^{1}$, Prof. MSc. Lubomir SOOS, PhD. ${ }^{2}$, Assoc. Prof. MSc. Peter BROKES, PhD. ${ }^{3}$}

\author{
${ }^{1}$ Multi Media Sunshine LTD. Milton Keynes, UK paul@mmsunshine4.freeserve.co.uk \\ ${ }^{2}$ Faculty of Mechanical Engineering, Slovak University of Technology Bratislava, Slovak Republic, \\ lubomir.soos@stuba.sk \\ ${ }^{3}$ Faculty of Mechanical Engineering, Slovak University of Technology Bratislava, Slovak Republic, \\ peter.brokes@stuba.sk
}

\begin{abstract}
This contribution is devoted to the development of an advanced vocational education and training system for professionals working in (or intending to enter) the waste management industry realized through the Leonardo project WASTRE. The consortium of the Project WASTRE includes 3 well known Technical Universities in Central Europe (TU Vienna, CVUT Prague and STU Bratislava). The project implements new didactical tools from projects EDUET, ELEVATE, RESNET and MENUET developed by MultiMedia SunShine, headed by Prof. Paul Callaghan for this education and training system. This system will be tested within courses organized by at least 3 institutions of vocational education and training: the Technical and vocational secondary school Tlmace, CHEWCON Humenne and the Union of Chambers of Craftsmen and Tradesmen of ESKISEHIR. The faculty of Mechanical Engineering (FME) of STU will coordinate the project WASTRE and will participate in the preparation of e-learning materials, organization of the courses and in the design of syllabuses, curricula, assessment and evaluation methods for the courses, the testing of developed learning materials, evaluating experiences from a pilot course and developing the e-learning materials according to the needs of end-users.
\end{abstract}

KEYWORDS: waste disposal, waste treatment, waste recycling, public authorities, SME managers, VET students and the unemployed, discriminated people, use of multimedia (music, sound effects, voiceovers, videos and animations) in interactive presentations, innovative software, sliders and popups.

\section{INTRODUCTION}

This project is aimed at the preservation of the environment and its natural resources, supporting the implementation of advanced technologies of waste treatment, disposal and recycling through the creation of an on-line system of distance learning, in order to enhance the knowledge, skills and competence of employees in various branches of agriculture and public authorities, SME managers, VET students and unemployed or discriminated people with the intention of improving their involvement in the labor market in the field of the most progressive technologies of waste treatment, disposal and recycling.

The consortium consists of 8 partners (Multimedia SunShine as innovation donator, 3 leading Central-European technical universities, and 3 organizations active in vocational training and the Recycling fund as a body organizing waste treatment and recycling in Slovakia) from 5 countries. The consortium members have good contacts with professionals active in waste treatment and 
SCIENTIFIC PROCEEDINGS 2011, Faculty of Mechanical Engineering, STU in Bratislava Vol. 19, 2011, pp. 134-141, DOI: 10.2478/v10228-011-0022-z

recycling as well as the necessary capacity and experience to carry out the implementation and propagation of the project results.

The tangible impact of the project is the implementation of new didactical tools developed in the projects ELEVATES, EDUET, RESNET and MENUET to on-line learning modules for waste treatment, waste disposal and waste recycling in the form of e-book, Moodle, and e-learning system. The intangible outcome is the transition of training and education from classroom "Talk and Chalk" to independent mobile e-learning in the fields of waste treatment and waste recycling.

The main outcome of the project WASTRE is to help solve the problems for producers to treat, dispose or recycle wastes from production processes, either from waste generated in production or waste generated after the use of products. The legal systems of the EU member states are unified on this issue and place emphasis on the complexity of waste management in enterprises. Technologies where waste problems are not solved sufficiently are not permitted to operate, thus entrepreneurs and managers are obliged to introduce effective and advanced technologies and equipment for waste treatment in their companies.

WASTRE modifies the role of education, skills and training in the field of waste treatment, disposal and recycling. Education and Training in this field can be considered in for the good of the public: an investment as important as self investment.

Many members of the target group live in regions located far from traditional educational centers. Classical methods of one way communication are not sufficient for them. E-learning is very flexible and enables continual improvements, updating and upgrading of the learning materials, adaptations to different knowledge and levels of course participants, utilizing materials from the internet and other information and communication technologies. E-learning contributes to combating all forms of discrimination 
SCIENTIFIC PROCEEDINGS 2011, Faculty of Mechanical Engineering, STU in Bratislava Vol. 19, 2011, pp. 134-141, DOI: 10.2478/v10228-011-0022-z
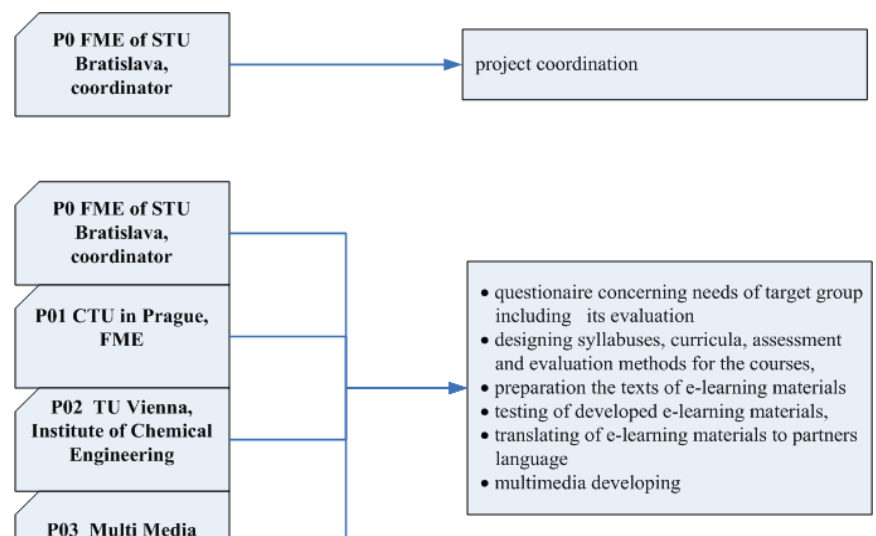

303 Multi Media Sun Shine
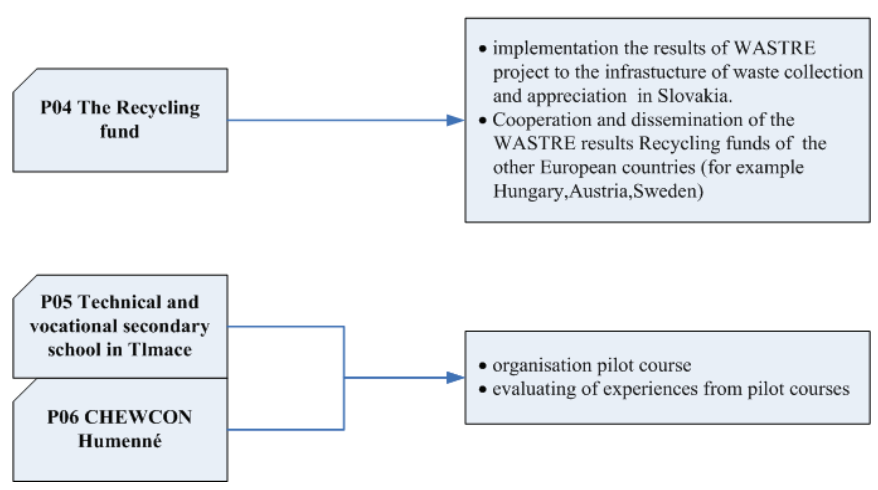

Fig. 1 Roles of the partners in the WASTRE project

\section{USE OF NEW DIDACTICAL TOOLS}

The new didactical tools developed in these projects to assist the transition from classroom "Talk and Chalk" to independent Mobile E-Learning include:

- The use of multimedia (music, sound effects, voiceovers, videos and animations) in interactive presentations, innovative software, sliders and popups.

- The use of interactive software and spreadsheets containing ActiveX controllers (scrollbars, dropdown selection boxes, etc.) for examining the effects of independent system variables on overall system performance.

- Quizzes, Games, Automatic Scoring, Feedback and Revision

- Storage and retrieval of data entered in interactive web forms.

- The use of Web2.0-based communication and collaboration technologies such as discussion forums, chat, e-mail, blogging, Wikipedia publishing systems, IP-based audio, videoconferencing and interactive TV.

\section{CONTENTS OF THE LEARNING MODULES}

The content of the e-learning study is divided into 4 modules. Module 1 consists of the waste management procedures and will include the following topics: 
SCIENTIFIC PROCEEDINGS 2011, Faculty of Mechanical Engineering, STU in Bratislava Vol. 19, 2011, pp. 134-141, DOI: 10.2478/v10228-011-0022-z

- Identification site and scope of audit.

- Obtaining bills for purchased items

- Obtaining bills for waste disposal

- Ascertaining charging for waste disposal.

- Waste disposal destination tracking - Landfill?

- Investigation of alternatives.

- Quantity estimation of waste.

- Estimation of onsite personnel.

- Waste quantity/person calculation.

- Comparison with similar sites.

- Analyses of options - straight rate of return.

- Produce ranked investment portfolio.

- Identify option conflicts

- Re-rank investment portfolio.

- Develop waste management strategy.

- Establish investment plan.

- Set up monitoring, targeting and project management systems.

Module 2 deals with EC action plans and directives, acts and regulations relating to waste and will include lists and explanations of examples from some of the major EC action plans and directives, national laws and regulations relating to waste and land pollution. Module 3 deals with solid and liquid waste treatment recycling technologies and equipment that will include the following topics:

- Waste Collection and Sorting

- Solid waste prepreparation (grinding, briquetting, pulverization)

- Landfilling

- Composting

- Incineration

- Solidification of hazardous waste

- Identification of options for waste reclamation.

- Identification of options for waste recycling: Plastics, Paper and cardboard, Glass, Metals, Ash (e.g. as soil conditioner, fillers for road building), Biodegradable, Pig bins, Curbside collection.

- Identification of problems of collection and sorting waste.

- Identification of options for waste reuse: bottles, containers, clothes, etc.

- Identification of options for waste incineration.

- Paper briquette production?

- Examination of uses for heat.

- Examination of possibilities for combined heat and power.

- Examine of possibilities for refuse-derived fuel production.

- Examine of possibilities for composting: Anaerobic, Aerobic.

- Vermocomposting

- Examination of possibilities for paralysis.

- Examination of possibilities for gasification.

- Examination of possibilities for hydrolysis/fermentation.

- Analyses of options - straight rate of return.

- Produce ranked investment portfolio. 
SCIENTIFIC PROCEEDINGS 2011, Faculty of Mechanical Engineering, STU in Bratislava Vol. 19, 2011, pp. 134-141, DOI: 10.2478/v10228-011-0022-z

- Identification option conflicts

- Re-rank investment portfolio.

- Development waste management strategy.

- Establishment investment plan.

- Set up monitoring and targeting and project management systems.

- Project management

For liquid waste treatment and recycling:

- Quality and quantity balancing,

- Rough filtration,

- Sedimentation,

- Flotation

- Physical-chemical and chemical treatment,

- Natural biological treatment,

- Activation

- Bio-filtration

- Secondary treatment of biologically treated water

- Disinfection

Physical-chemical treatment:

- Absorption

- Extraction

- Ion exchange

- Membrane separation processes

- Radio-chemical processes

- Distillation

- Electrochemical processes

Finally Module 4 deals with the evaluation of alternatives of waste treatment recycling technologies and equipment and will include the examination and classification of solid wastes as:

- Combustible

- Compostible - biodegradable

- Paper and cardboard.

- Glass.

- Metals - tins and cans.

- Textiles.

- Plastics.

- Ash.

- Water content.

- Disposable products.

Examination and classification of liquid wastes:

- Paints.

- Solvents.

- Oils.

- Acids. 
SCIENTIFIC PROCEEDINGS 2011, Faculty of Mechanical Engineering, STU in Bratislava Vol. 19, 2011, pp. 134-141, DOI: 10.2478/v10228-011-0022-z

- Alkalis.

- Liquid fuels.

Examination and classification of gaseous and vaporous wastes:

- CFCs

- Solvents.

- Possible routes of entry for humans/animals (inhalation, ingestion, skin or Eye contact)

- Exposure limits and degree of carcinogenicity,

- Precautions for handling and using,

- Emergency first-aid required,

- Supplier information.

Record of hazardous wastes:

- Chemicals and common names

- Chemicals and physical characteristics

- Physical and health hazards

- Possible routes of entry for humans/animals (inhalation, ingestion, skin or

- eye contact)

- Exposure limits and degree of carcinogenicity

- Precautions for handling and using

- Emergency first-aid required

- Supplier information

- Attention to storage areas.

- Investigation of standards, regulations, acts and legislation applicable.

- Identification of possible fines and penalties for illegal dumping.

- Identification of needs for clean-up.

As well as the identification of options for reducing waste quantities: whether the product is necessary, Package reduction, Efficiencies of materials processing etc.

\section{CONCLUSION}

Current EU waste policy is based on a concept known as the waste hierarchy. This means that, ideally, waste generation should be prevented or reduced, and that which is generated should be recovered as much as possible through means of re-use, recycling and other recovery operations, thus reducing load on disposal operations. This hierarchy is likely to be strengthened by improvements in technology and techniques as well as educational systems in this field.

The project WASTRE will contribute to the realization of this concept by the development of ON-LINE LEARNING MODULES FOR WASTE TREATMENT, WASTE DISPOSAL AND WASTE RECYCLING for the target group, including professionals in various branches of the industry, agricultural and public authorities, SME managers, VET students and the unemployed or descriminated with the intention of improving their opportunities in the labor market.

\section{ACKNOWEDGEMENT}

The paper was prepared within the LEONARDO DA VINCI project registration number 11310 1621 
SCIENTIFIC PROCEEDINGS 2011, Faculty of Mechanical Engineering, STU in Bratislava Vol. 19, 2011, pp. 134-141, DOI: 10.2478/v10228-011-0022-z

\section{REFERENCES}

[1] ŠOOŠ, Lubomír; VOZÁR, Peter; TIRPÁK, Ivan; ŠPÁNIKOVÁ, Daniela: Law in the area of EPWMR=Zakonodavstvo u oblasti zaštite životne sredine, upravljanja otpadom i reciklaža u Slovačkoj.In: Guide for the development of environmental protection, waste management and recycling in Serbia $=$ Priručnik za unapredenje zaštite životne sredine, upravljanja otpadom i reciklaža u Serbiji : Tempus project SM_SCM-C037B06-2006 (RS) Improvement and development of the ecological attitude in Serbia IDEAS - Tempus projekat Unapredenje i razvoj stanja zaštite životne sredine u Srbiji. - Novi Sad : Fakultet techničkich nauka, 2008. - ISBN 978-86-7892-115-5. - S. 51-58

[2] DOUGIAMAS M.: 2003. Moodle Documentation Dostupné na Internete: http://www.moodle.com/doc/

[3] CHLEBEC J.: Využitie rozl'ahlých počítačových sietí vo výučbe predmetov výpočtovej techniky a informatiky.Bakalárska práca

[4] ILAVSKÁ, A.: Príručka pre tútorov dištančného vzdelávania. 1. vyd. Nitra : SPU Nitra, 2001. 28 s. ISBN 80-7137-965-4

[5] KVETOŇ, K.: Základy distančního a online vzdělávání. 1. vyd. Praha : ČVUT Praha, 2003. 92 s. ISBN 80-01-02715-5

[6] MUDRÁK, D.: Online vzdělávací prostř̌edí Moodle Dostupné na Internete: http://kraken.pedf.cuni.cz/moodle/mod/resource/view.php?id=78

[7] ORBÁNOVÁ, I.: Vzdelávacie programy a kurzy dištančného vzdelávania. vyd. Nitra : SPU Nitra, 2001. 24 s. ISBN 80-7137-966-2

[8] KOLLÁR, V.; BROKEŠ, P.: Testovanie e-learningových kurzov Claroline pri environmentálnom vzdelávaní. In: Nová Ekonomika, vedecký časopis Obchodnej fakulty Ekonomickej univerzity v Bratislave, Číslo 1 (10) marec 2005, Ročník 4, s.59-67.

[9] KOLLÁR, V.; BROKEŠ, P.: Prekážky zavádzania systémov environmentálneho manažérstva do malých a stredných podnikov a možnosti ich prekonávania. In Vedecký časopis Podniková revue, ročník IV, číslo 7/2005. , s. 7- 19.

[10] KOLLÁR, V.; BROKEŠ, P.: Environmentálny manažment. Sprint, máj 2005, 326 s., ISBN 8089085-37-7.

[11]TURČÁNI, M.; NOVÁČIK, T. 2003 Možnosti e-Learningu pri príprave odborníkov pre Informačnú spoločnost'. In: E-learn 2003. Žilina : Žilinská Univerzita

[12] ŠOOŠ, L’ubomír ; HODOLIČ, Janko: Upravljanje otpadom u Slovačkoj. - 1. vyd. - Novi Sad : Fakultet tehničkih nauka, 2008. - 279 s. - ISBN 978-86-7892-110-0

[13] ŠOOŠ, Lubomír ; KOLLÁTH, Ludovít ; KRÍŽIK, Peter: Energetické zhodnocovanie kalov z ČOV - cesta menšieh zla. In: Odpady - Luhačovice 2006. XIV. mezinárodní kongres a výstava : Sborník přednášek / nadát. Odpady - Luhačovice 2006. Luhačovice, 19.-21.9. 2006. - Praha : CEMC, 2006. - S. 225-233

[14]BROKEŠ, Peter ; KOLLÁR, Vojtech ; NOVÁK, Luboš ; RUIZ, Jean Michel ; STERNER, Rigmor: Petites et moyennes entreprises et l'environnement : Module 3. - Bratislava : Ekonóm, 2004. - 112 s. - ISBN 80-225-1924-3

[15] KOLLÁR, Vojtech ; BROKEŠ, Peter: Environmentálny manažment. - Bratislava : Sprint vfra, 2005. - 326 s. - ISBN 80-89085-37-7

[15] Paul W O'CALLAGHAN, Integrated Environmental Management Handbook, John Wiley \& Sons Ltd. 1996. ISBN 0-471-963342-9

[16] EDUET http://www.infoart-bg.com/en/international_projects/eduet/

[17] ELEVATE http://www.elevate-project.org/

[18] RESNET http://www.resnet-project.org/

[19] MENUET http://141.85.252.215/menuet/index.php/about.html 
SCIENTIFIC PROCEEDINGS 2011, Faculty of Mechanical Engineering, STU in Bratislava Vol. 19, 2011, pp. 134-141, DOI: 10.2478/v10228-011-0022-z

[20] WASTRE http://redilem.sjf.stuba.sk/ 